\title{
Peningkatan pengetahuan masyarakat tentang perlindungan anak dari aspek pendidikan, hukum, dan kesehatan di Desa Tambun Kecamatan Bandar Petalangan
}

\author{
Ulfia Hasanah*, Hayatul Ismi, Ihda Hasbiyati, Maimunah, Rismadefi Woferst, \& Yenni \\ Kusumawati
}

Fakultas Hukum, Universitas Riau

*ulfia.hasanah@lecturer.unri.ac.id

\begin{abstract}
Abstrak. Di tengah masyarakat ditemukan beberapa permasalahan terhadap anak di bidang Pendidikan, Hukum dan Kesehatan. Masih ditemukan anak usia di bawah 18 tahun yang dieksploitasi sebagai pekerja seksual komersial; anak berkonflik dengan hukum, anak usia 10-18 tahun bekerja di sektor informal, anak yang meninggalkan bangku sekolah dasar sebelum tamat atau tidak melanjutkan ke jenjang selanjutnya karena akses dan ekonomi; kasus adopsi dilakukan di luar prosedur standar administrasi kependudukan; ditemukannya anak-anak yang stunting. Untuk itu diperlukan suatu upaya untuk meningkatkan pemahaman masyarakat terkait perlindungan terhadap anak.Salah satu yang memiliki tanggung jawab dalam memberikan perlindungan kepada anak adalah Orangtua. Kegiatan Pengabdian ini dilakukan dengan memberikan pengetahuan tentang Peran Orang Tua dan Masyarakat dalam pemberian perlindungan kepada Anak. Kegiatan ini bertujuan meningkatkan pemahaman masyarakat tentang Perlindungan Anak dari segi pendidikan, hukum dan kesehatan sehingga masyarakat dapat memahami pentingnya perlindungan terhadap anak. Kegiatan Pengabdian di Desa Tambun ini dapat dikatakan berhasil. Adanya permintaan dari peserta agar kegiatan ini dilanjutkan. Masyarakat Desa Tambun berharap untuk kegiatan selanjutnya diberikan pelatihan lanjutan terkait Skill-skill yang diperlukan oleh orang tua serta masyarakat. Untuk Tindak Lanjut kegiatan ini dibuat WA Grup para orang tua serta masyarakat yang telah mengikuti program Sosialisasi, wadah komunikasi antara Tim Pengabdian dengan masyarakat setempat.
\end{abstract}

Kata Kunci: pengetahuan, perlindungan, anak, Desa Tambun, Pelalawan

\begin{abstract}
There are several problems in the community with children in the fields of Education, Law and Health. There are still children under 18 years of age who are exploited as commercial sexual workers; children in conflict with the law, children aged 10-18 Years work in the informal sector, children who leave primary school before graduating or do not continue to the next level due to access and economy; adoption cases are carried out outside the standard population administration procedures; the discovery of stunted children. So, it is necessary to increase public understanding regarding child protection. One of those who have the responsibility of providing protection to children is the parent, the service program is carried out by providing material related to the role of parents and society in providing protection to children. The delivery of this material aims to provide an understanding of child protection in terms of education, law and health so that the public can understand the importance of protecting children. This service activity in Tambun Village can be said to be successful. There was a request from the participants to continue this activity. The people of Tambun Village hope that for further activities, further training is given regarding the skills needed by parents and the community. To increase community understanding, the WA Group was also created, whose members are parents who have participated in the Socialization program, this group aims to be a forum for communication between the Service Team and the local community.
\end{abstract}

Keywords: knowledge, protection, children, Tambun Village, Pelalawan

To cite this article: Hasanah, U., H. Ismi., I. Hasbiyati., Maimunah., R. Woferst., \& Y. Kusumawati. 2020.

Peningkatan pengetahuan masyarakat tentang perlindungan anak dari aspek pendidikan, hukum, dan kesehatan di

Desa Tambun Kecamatan Bandar Petalangan. Unri Conference Series: Community Engagement 2: 359-365

https://doi.org/10.31258/unricsce.2.359-365

(C) 2020 Authors

Peer-review under responsibility of the organizing committee of Seminar Nasional Pemberdayaan Masyarakat 2020 


\section{PENDAHULUAN}

Anak adalah amanah sekaligus karunia Tuhan Yang Maha Esa, yang senantiasa harus kita jaga karena dalam dirinya melekat harkat, martabat, dan hak-hak sebagai manusia yang harus dijunjung tinggi. Hak asasi anak merupakan bagian dari hak asasi manusia yang termuat dalam Undang-Undang Dasar 1945 dan Konvensi Perserikatan Bangsa-Bangsa tentang hak-hak Anak.

Undang-undang Nomor 39 Tahun 1999 Tentang Hak Asasi Manusia telah mencantumkan tentang hak anak, pelaksanaan kewajiban dan tanggung jawab orang tua, keluarga, masyarakat, pemerintah, dan negara untuk memberikan perlindungan pada anak masih memerlukan suatu undang-undang mengenai perlindungan anak sebagai landasan yuridis bagi pelaksanaan kewajiban dan tanggung jawab tersebut.(Akhmad Sofian, 2012) Dengan demikian, pembentukan undang-undang ini didasarkan pada pertimbangan bahwa perlindungan anak dalam segala aspeknya merupakan bagian dari kegiatan pembangunan nasional, khususnya dalam memajukan kehidupan berbangsa dan bernegara. Orang tua, keluarga, dan masyarakat bertanggung jawab untuk menjaga dan memelihara hak asasi tersebut sesuai dengan kewajiban yang dibebankan oleh hukum. (Nashriana, 2011)

Undang-undang Nomor 35 Tahun 2014 Tentang Perlindungan Anak menegaskan bahwa pertanggungjawaban orang tua, keluarga, masyarakat, pemerintah dan negara merupakan rangkaian kegiatan yang dilaksanakan secara terus-menerus demi terlindunginya hak-hak anak. Upaya perlindungan anak perlu dilaksanakan sedini mungkin, yakni sejak dari janin dalam kandungan sampai anak berumur 18 (delapan belas) tahun. Bertitik tolak dari konsepsi perlindungan anak yang utuh, menyeluruh, dan komprehensif, undangundang ini meletakkan kewajiban memberikan perlindungan kepada anak berdasarkan asas-asas sebagai berikut: non diskriminasi; kepentingan yang terbaik bagi anak; hak untuk hidup, kelangsungan hidup, dan perkembangan; dan penghargaan terhadap pendapat anak (Rika Saraswati, 2015).

Pembinaan, pengembangan dan perlindungan anak, memerlukan peran masyarakat, baik melalui lembaga perlindungan anak, lembaga keagamaan, lembaga swadaya masyarakat, organisasi kemasyarakatan, organisasi sosial, dunia usaha, media massa, atau lembaga pendidikan. Dilandasi kesadaran bahwa masa depan masyarakat, bangsa, dan umat manusia ditentukan oleh kesejahteraan anak saat ini, maka pemenuhan hak-hak anak untuk tumbuh dan berkembang mencapai tingkat optimum potensi yang dimilikinya dalam lingkungan keluarga dan masyarakat yang melindungi harus menjadi issue yang penting dari semua kalangan. Data resmi statistik dan pengamatan kasat mata menunjukkan bahwa pada kenyataannya masih terdapat kesenjangan yang sangat besar antara situasi ideal dengan situasi nyata terhadap penghargaan, pemenuhan, dan perlindungan atas hak-hak anak.

Ketersediaan sarana/prasarana pendidikan berkualitas dan aksesnya merupakan masalah, sebagaimana juga untuk layanan kesehatan; banyak ditemukan anak berusia di bawah 18 tahun yang dieksploitasi sebagai pekerja seksual komersial; ditemukan anak yang berkonflik dengan hukum dan "diproses" secara hukum sebagaimana pelaku tindak kriminal lainnya; banyak anak terlantar yang mencari hidup di jalan; banyak anak usia 10-18 tahun bekerja di sektor informal di pertokoan ataupun perumahan; banyak anak dari kelompok masyarakat yang meninggalkan bangku sekolah dasar sebelum tamat atau tidak melanjutkan ke jenjang selanjutnya karena masalah akses dan ekonomi; banyak panti asuhan sangat minim fasilitasnya; sangat sedikit sekolah untuk anak cacat; bahwa banyak kasus adopsi dilakukan di luar prosedur standar administrasi kependudukan; suara anak belum dipertimbangkan dalam berbagai proses perencanaan pembangunan wilayah; dan lain-lain. Kekerasan juga sering terjadi ketika orang tua memaksa anak yang masih berusia di bawah umur untuk dapat memberikan kontribusi ekonomi keluarga, sehingga fenomena penjual korban, pengamen jalanan, pengemis anak, dan lain-lain kian merebak terutama di perkotaan (Bagong Suyanto, 2016: 2930). Orang tua sebagai orang yang pertama kali ditemui anak setelah melahirkan seyogyanya orang tua mendukung perlindungan anak. Anak akan bersama orangtua dari dalam kandungan sampai dengan besarnya nanti, anak selalu butuh perlindungan dan kasih sayang. Orang tua yang menelantarkan dan tidak mau melindungi anak, akan menciptakan anak yang tidak baik nantinya, karena akan banyak menyusahkan masyarakat. Maka daripada itu perlindungan adalah suatu hukum yang wajib untuk dipenuhi oleh orang tua (Cunduk Wasiati, 2020).

Berdasarkan Pasal 4 Undang-undang Nomor 35 Tahun 2014 Tentang Perlindungan Anak dinyatakan bahwa "Setiap anak berhak untuk dapat hidup, tumbuh berkembang dan berpartisipasi secara wajar sesuai dengan harkat dan martabat kemanusiaan, serta mendapat perlindungan dari kekerasan dan diskriminasi. Perlindungan anak terkait erat dengan lima pilar yakni, orang tua, keluarga, masyarakat, pemerintah, pemerintah daerah dan negara. Kelimanya memiliki keterkaitan satu sama lain sebagai penyelenggara 
perlindungan anak. Dalam bentuknya yang paling sederhana, perlindungan anak mengupayakan agar setiap hak anak tidak dirugikan. Perlindungan anak bersifat melengkapi hak-hak lainnya menjamin bahwa anak-anak akan menerima apa yang mereka butuhkan agar mereka dapat bertahan hidup, berkembang dan tumbuh. Akan tetapi pada kenyataannya kondisi anak-anak di Indonesia masih sangat memprihatinkan terutama yang menyangkut masalah pekerja anak, anak jalanan, dan anak-anak korban kekerasan seksual, eksploitasi seksual, dan eksploitasi seksual komersial (Rini Fitriani, 2016)

Anak tidak dapat dipungkiri merupakan masa depan bangsa. Anak adalah penerus cita-cita kemerdekaan dan kelangsungan hajat hidup bangsa dan Negara. Bangsa Indonesia masih mengalami banyak permasalahan dalam pemberian perlindungan terhadap anak. Hal ini terbukti dengan masih banyaknya kasus eksploitasi, kekerasan dan tindak pidana terhadap Anak. Sekitar 6.000 anak berhadapan dengan hukum, 5000 anak berada di Lembaga Pemasyarakatan, serta ribuan anak-anak dengan segala macam permasalahan lainnya (Hermawan Salim, C. 2016). Maraknya kasus kekerasan terhadap anak pada akhir-akhir ini, salah satunya adalah Kasus Iqbal yang dianiaya oleh teman lelaki ibunya, sementara di daerah Kampar, Provinsi Riau adalah kasus Adit yang dianiaya oleh ibunya sendiri, selain itu yang terbaru adalah terkait dengan pencabulan terhadap anak yang kasusnya marak terjadi akhir-akhir ini.

Secara nasional, Provinsi Riau merupakan peringkat kedua kasus kekerasan pada anak setelah Jawa Timur. Yang menarik dari kasus kekerasan ini adalah kekerasan yang terjadi dalam lingkungan keluarga. Kekerasan pada anak dalam keluarga seringkali dianggap hal yang wajar sebagai bagian dari pendidikan anak (Devi Risma, 2020). Banyaknya kasus-kasus eksploitasi terhadap anak turut membuktikan bahwa pemahaman terhadap perlindungan Anak belum terlaksana dengan baik. Pada Saat ini pemerintah telah membuat peraturan terkait dengan pelaku kejahatan terhadap anak. Terutama terhadap pelaku kejahatan seksual terhadap anak. Sejak Januari hingga Oktober 2019, ada 90 kasus kekerasan terjadi terhadap anak di Kota Pekanbaru, ini belum ditambah lagi dengan kasus-kasus di kabupaten lainnya di Provinsi. Sehubungan dengan hal ini maka perlu melakukan kegiatan pengabdian kepada masyarakat mengenai "Peningkatan Pengetahuan Masyarakat Tentang Perlindungan Anak dari Aspek Pendidikan, Hukum dan Kesehatan Di Desa Tambun Kecamatan Bandar Petalangan Kabupaten Pelalawan."

\section{METODE PENERAPAN}

Orang tua merukakan salah satu yang memiliki peranan utama dalam memberikan perlindungan kepada anak. Beberapa tahapan dalam pendekatan Penyelesaian masalah, yaitu memilih kelompok sasaran yang tepat, pelaksanaan kegiatan Pengabdian kepada masyarakat sasaran, Evaluasi serta Monitoring untuk melihat apakah program peningkatan pengetahuan masyarakat dapat berlangsung dengan baik. Tahapan pendekatan digambarkan sebagai berikut:

a. Pemilihan Kelompok Sasaran

Kegiatan Pengabdian bertujuan untuk meningkatkan pemahaman masyarakat tentang pentingnya perlindungan terhadap anak baik dari segi pendidikan, hukum serta kesehatan. Tahapan pertama yang dilakukan adalah memilih kelompok sasaran. Kelompok Sasaran yang dipilih adalah Ketua RT/ RW setempat, Perwakilan orang tua, serta Kader Posyandu. Kegiatan ini dilakukan oleh Tim dengan Kepada Desa Setempat. Pemilihan kelompok sasaran ini didasarkan kepada Peran kelompok sasaran di dalam masyarakat.

b. Sosialisasi Peningkatan Pengetahuan masyarakat tentang Perlindungan anak dari segi pendidikan, hukum dan kesehatan. Kegiatan pengabdian berkolaborasi dengan Mahasiswa Kukerta Universitas Riau Tahun 2020 di Desa Tambun. Pelaksanaan Pengabdian juga bekerjasama dengan Ketua Posyandu/Bidan Setempat untuk mendapatkan materi serta sharing informasi.

Adapun kegiatan tersebut adalah sebagai berikut :

1. Program kerja yang berkaitan dengan pemenuhan hak -hak anak dibidang pendidikan, hukum dan kesehatan dimulai pada tanggal 20 Juli 2020. Diawali dengan Penyuluhan Cuci Tangan dan Penyuluhan Cara Menyikat Gigi Yang Baik Dan Benar yang diberikan kepada anak-anak SD di Desa Tambun, yang bertujuan untuk meningkatkan pengetahuan anak dibidang kesehatan.

2. Sosialisasi Pengetahuan Masyarakat Tentang Anak Dari Aspek Kesehatan dan Pendidikan Kegiatan ini dilakukan pada tanggal 03 Agustus 2020, kegiatan ini dilakukan untuk memberikan pengetahuan tentang hak-hak anak dibidang pendidikan dan Peran yang dapat orang tua dalam bidang Pendidikan di masa Pandemic Covid-19. 
3. Penyampaian materi Tentang Stunting yang disampaikan kepada peserta posyandu, pada tanggal 15 Agustus 2020, kegiatan ini dilakukan untuk memberikan informasi tentang stunting, penyebab stunting dan bahaya stunting serta upaya pencegahan stunting.

4. Kegiatan Peningkatan Pengetahuan Masyarakat Tentang Anak Dari Aspek Kesehatan Dan Pendidikan, dilakukan pada tanggal 20 Agustus 2020, kegiatan ini dilakukan untuk memberikan pengetahuan Dibidang kesehatan dengan memberikan penyuluhan tentang perilaku hidup sehat, Misalnya dengan memberikan informasi tentang pangan berbahaya kepada masyarakat. Diharapkan orang tua dapat menginformasikan kepada anggota keluarganya Tentang pangan yang berbahaya, dan diharapkan tidak memberikan pangan yang berbahaya ini kepada anak-anak dan keluarganya. Dibidang Hukum disampaikan hak-hak anak secara hukum sebagaimana diatur dalam Undang-undang Nomor 35 Tahun 2014 Tentang Perlindungan Anak. Penyampaian materi tentang Bullying serta akibat dari perbuatan bullying serta ancaman hukum bagi pelaku bullying. Disamping itu juga disampaikan materi tentang Bijak bermedia sosial kepada masyarakat, agar tidak ada warga masyarakat yang berurusan dengan Hukum.

5. Seminar Tentang Penting Bahasa Inggris Di Era 4.0 dilakukan pada selama bulan agustus, yang bertujuan untuk memberikan pengetahuan tentang bahasa Asing kepada anak-anak SD di Desa Tambun.

c. Evaluasi dan Monitoring

Evaluasi dan Monitoring dilakukan untuk mengetahui hasil dari kegiatan pengabdian. Evaluasi dilakukan sesudah kegiatan pengabdian dilakukan. Terkait dengan pemahaman dan penyebarluasan pengetahuan perlindungan terhadap anak dari segi pendidikan, hukum dan kesehatan. Tahapan evaluasi adalah sebagai berikut:

1. Evaluasi dan monitoring selama kegiatan berlangsung pada tahap ini peserta dilihat pemahamannya tentang hak-hak anak. Pada tahapan ini juga disebarkan kuesioner tentang Peranan orang tua dalam dalam memberikan perlindungan anak dari segi pendidikan.

2. Evaluasi dilakukan menggunakan Kuesioner. Kuesioner untuk mengukur peningkatan pemahaman peserta diukur dengan menggunakan pengetahuan responden serta dampak kegiatan yang diberikan setelah kegiatan berlangsung. Kuesioner berisi jawaban iya atau tidak, dan peserta diminta untuk memilih jawaban ya atau tidak.

3. Monitoring setelah kegiatan selesai dilakukan. Perkembangan pengetahuan dan penyebaran pengetahuan tersebut diamati dari komunikasi yang terjadi pada Grup Media Sosial yang yang dibuat.

\section{HASIL DAN KETERCAPAIAN SASARAN}

Kegiatan Pengabdian dilakukan dengan memberikan pengetahuan kepada masyarakat tentang perlindungan hukum terhadap anak dari segi pendidikan, hukum dan kesehatan. Solusi pemberdayaan yaitu dengan memberikan informasi melalui kegiatan sosialisasi dan praktek secara langsung bersama masyarakat. Kegiatan peningkatan pengetahuan masyarakat tentang perlindungan terhadap hak-hak anak dilakukan dengan kegiatan sosialisasi dan juga praktik yang diharapkan dapat meningkatkan pengetahuan masyarakat dalam pemenuhan hak anak di bidang pendidikan, hukum dan kesehatan. Peningkatan pengetahuan masyarakat tentang hak -hak anak di bidang pendidikan dilakukan dengan memberikan pelatihan bagaimana menjadi guru bagi anak, terutama pada masa pandemic ini. Kepada orang tua diberikan trik-trik untuk yang dapat membantu orangtua untuk melaksanakan peran ini.

Di bidang kesehatan diantaranya dilakukan dengan memberikan penyuluhan tentang perilaku hidup sehat, seperti informasi tentang pangan berbahaya kepada masyarakat. Diharapkan orang tua dapat memberitahukan kepada anak-anak tentang pangan yang berbahaya, dan diharapkan meminimalisir pemberian pangan yang berbahaya ini kepada anak-anak dan keluarganya. Dibidang Hukum Disampaikan hak-hak anak secara hukum sebagaimana diatur dalam Undang-undang Nomor 35 Tahun 2014 Tentang Perlindungan Anak. Dalam hal ini juga disampaikan materi tentang bullying serta akibat dari perbuatan bullying serta ancaman hukum bagi pelaku bullying. Disamping itu juga disampaikan materi tentang Bijak bermedia sosial kepada masyarakat, agar tidak ada warga masyarakat yang berurusan dengan Hukum.

Selain itu mahasiswa Kukerta Integrasi Abdimas Universitas Riau Tahun 2020 juga memberikan pengetahuan kepada masyarakat, yaitu terkait Perilaku Hidup Bersih. Materi ini berkaitan tentang tata cara cuci tangan yang benar. Praktik ini yang disampaikan kepada anak-anak sekolah Dasar di Desa Tambun. Kepada warga masyarakat juga diberikan informasi terkait wabah Covid-19 yang melanda saat ini dan 
disampaikan juga beberapa kiat agar terhindar dari Covid-19, Kepada masyarakat juga disampaikan materi tentang Stunting.

\section{Materi kegiatan meliputi sebagai berikut:}

a. Penyampaian Materi Tentang Peranan Keluarga Dalam Pendidikan, materi ini berkaitan dengan Tugas Orang Tua dalam Memperhatikan pendidikan Anaknya, Pentingnya Orangtua mengetahui Karakteristik Anak, serta Mengembangkan Potensi dan bakat anak-anaknya. Kegiatan ini berkolaborasi dengan mahasiswa Kukerta Universitas Riau Tahun 2020, yang mana kepada anak-anak diberikan juga pendampingan pembelajaran pada masa Pandemic, karena sebagian besar anak-anak tidak belajar selama sekolah mereka diliburkan.

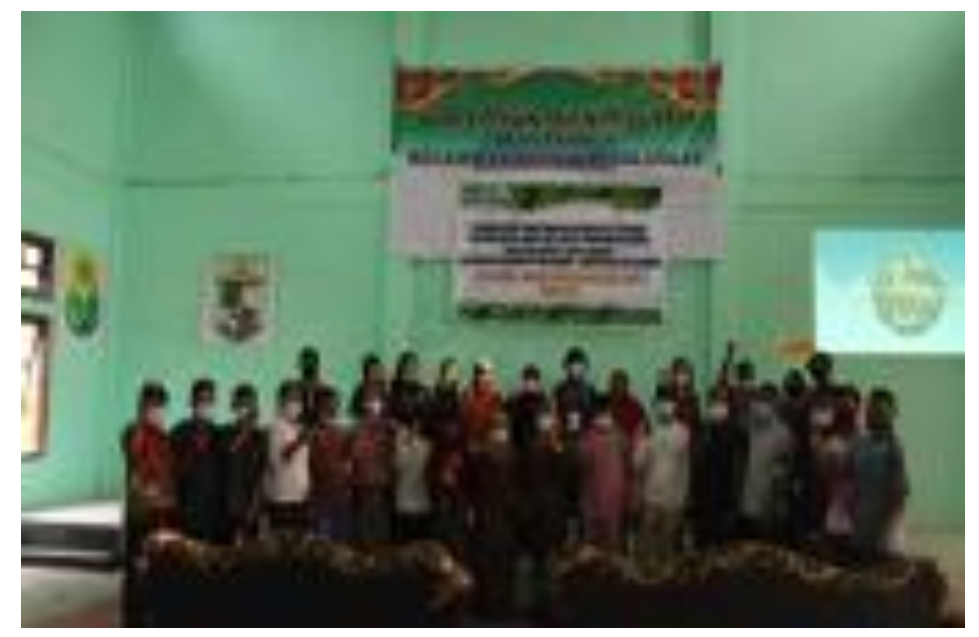

Gambar 1. Kegiatan Peningkatan Pengetahuan Orang Tua dalam pemberian Perlindungan Anak dari Aspek Pendidikan Dan Kesehatan

b. Selanjutnya adalah Penyampaian Materi keterkaitan peningkatan perlindungan Anak diBidang Kesehatan yaitu terkait Masalah stunting pada anak. Kepada para peserta juga diberikan Brosur berkaitan dengan materi yang diberikan.

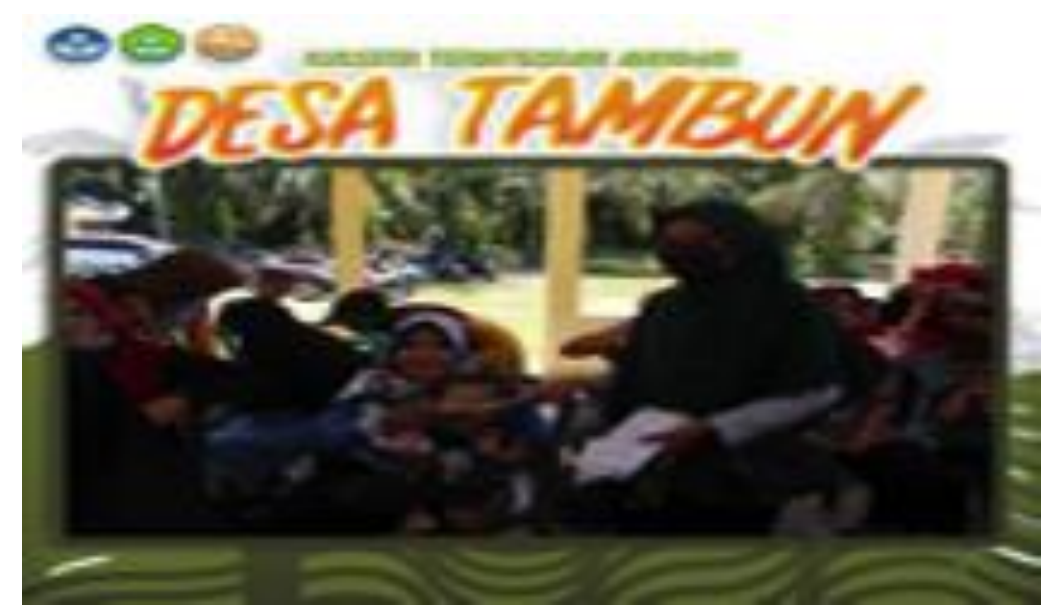

Gambar 2. Penyampaian materi tentang stunting Kepada Anggota Posyandu

c. Sehubungan dengan adanya Pandemic Corona, dalam hal ini Tim Pengabdian juga memberikan penyuluhan kepada masyarakat terkait virus Corona. Kegiatan ini juga bertujuan untuk memberikan edukasi kepada orangtua tentang bahaya COVID dan diharapkan ketika orangtua sudah memahami, mereka dapat menyampaikan informasi COVID ini kepada anak dan keluarga masing-masing. 

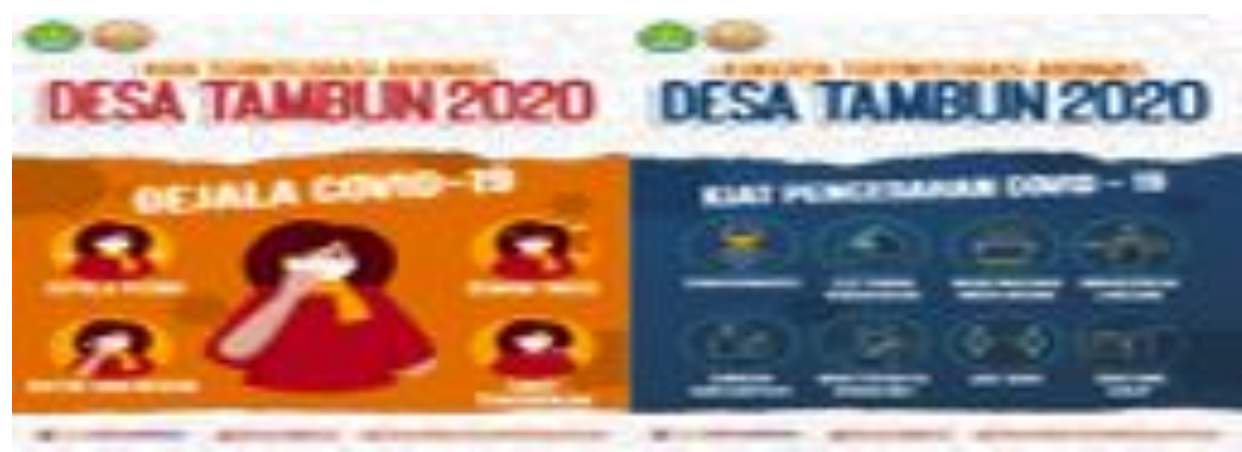

Gambar 3. Brosur Terkait Covid-19 dan cara pencegahannya

d. Diberikan juga materi tentang Perilaku Hidup Bersih seperti cara cuci tangan yang benar.

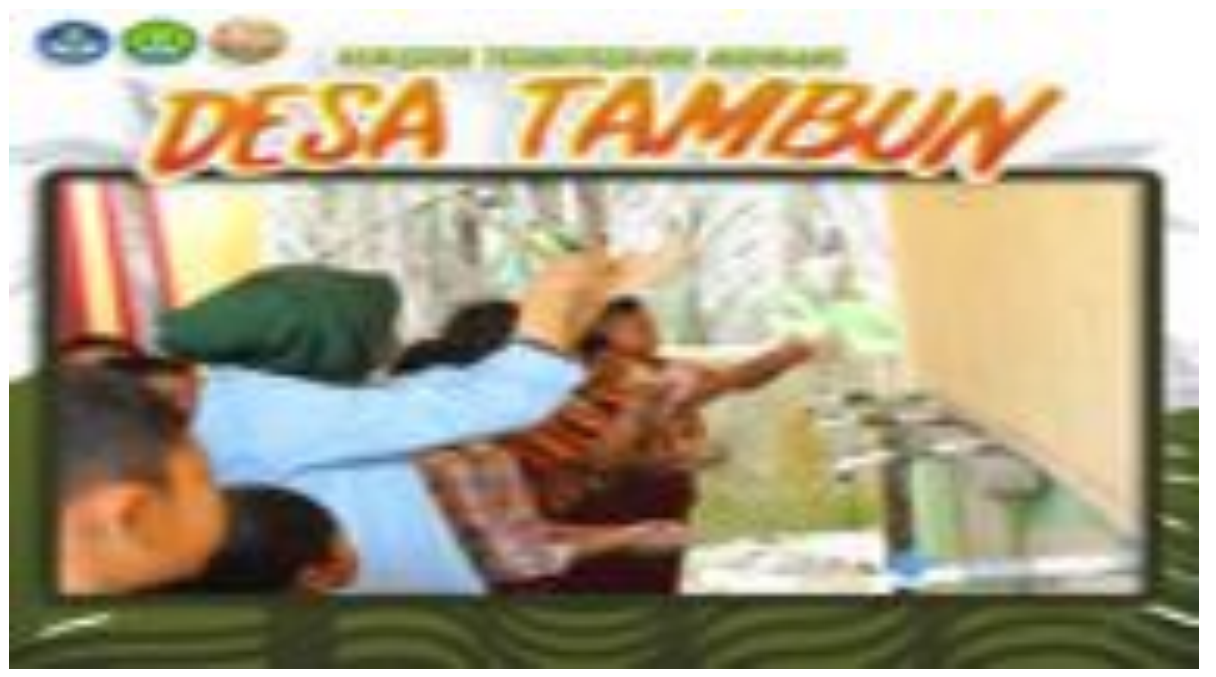

Gambar 4. Kegiatan Pelatihan cara Cuci Tangan yang Benar Kepada Anak Sekolah Dasar

Secara umum, pelaksanaan kegiatan peningkatan pengetahuan masyarakat dalam pemberian perlindungan kepada anak di desa Tambun dapat dikatakan berhasil. Hal ini dapat dilihat dari permintaan peserta agar kegiatan ini dapat dilanjutkan. Secara spesifik, aparat dan masyarakat Desa Tambun berharap untuk dilakukan kegiatan. Masyarakat mengharapkan Agar ke depan dapat diberikan pelatihan lanjutan terkait Skill-skill yang diperlukan dalam menjalankan Peran Sebagai Orang Tua. Hal ini tentu akan menambah wawasan dan pengetahuan para orangtua sehingga memudahkan mereka dalam menjalankan tugasnya dalam memenuhi hakhak terhadap anak. Penyebarluasan informasi juga dilakukan melalui Media Sosial yang dimiliki Peserta. Dari kegiatan ini dibuat Grup Whatsapp yang beranggotakan peserta kegiatan pengabdian. Ketercapaian juga dilihat dari beberapa luaran yang telah dihasilkan yaitu: logbook, youtube, dan publikasi media, serta pembuatan beberapa prosedur yang terkait dengan pemenuhan hak-hak anak.

\section{KESIMPULAN}

Orangtua memiliki peranan yang besar dalam memberikan perlindungan kepada anak. Agar orang tua dapat melaksanakan perannya dengan baik, maka perlu diberikan pengetahuan dan pemahaman kepada orang tua. Perlu ditentukan siapa saja yang memiliki peranan utama dalam hal ini. Yaitu mereka yang memiliki peranan utama dalam masyarakat. Salah satu cara untuk meningkatkan pengetahuan masyarakat adalah dengan memberikan penyuluhan dan pelatihan. Kegiatan ini dapat dikatakan berhasil, tetapi tetap perlu dilakukan penelitian yang lebih lanjut terkait Perlindungan terhadap Anak. 


\section{UCAPAN TERIMAKASIH}

1. Kepala Desa Tambun, Kabupaten Pelalawan

2. LPPM Universitas Riau

3. Seluruh tim Pengabdian Kepada Masyarakat Desa Tambun

\section{DAFTAR PUSTAKA}

Nashriana. 2010. Perlindungan Hukum Pidana Terhadap Anak di Indonesia. Rajawali Press, Jakarta.

Saraswati, Rika. 2009. Hukum Perlindungan Anak di Indonesia. PT. Citra Aditya Bakti, Bandung.

Sofian, Ahmad. 2011. Perlindungan Anak di Indonesia: Dilema dan Solusinya. Penerbit: PT. Sofmedia, Jakarta.

Chumaidi, Lufhti dan Ridwan Tayeb. 2013. Kekerasan terhadap anak: Fakta, persepsi dan Respon Daerah. KPAI. Jakarta.

UUD 1945

Undang-undang Nomor 39 Tahun 1999 Tentang Hak Asasi Manusia

Undang-Undang Nomor 35 Tahun 2014 Tentang Perlindungan Anak

Antara Riau, terakhir diakses 05 Januari 2020

Vivanews.com

https://pekanbaru.tribunnews.com/2019/11/27/siswa-smp-pelaku-bully-jadi-tersangka-kadisdik-harap-pelaku-tetapsekolah-kasus-bullyingdiRiau) 